\title{
Epistemology of epidemiology: the case of Ungdata
}

\author{
Ida Hydle \\ UiT-Norges Arktiske Universitet, Institutt for barnevern og sosialt arbeid \\ Email: ida.hydle@uit.no Telephone:+4790507615
}

\begin{abstract}
One of the most significant epidemiological tools for the perceived truth about contemporary Norwegian youth is in Ungdata, Youth Data. This is a continuous online-based survey grounded upon several and varying investigations of youth in Norwegian high schools, now extending to primary schools as well. The knowledge bases, epidemiological practices, technicalities, economic premises for the work and also data publishing is handled by social scientists at Norwegian Social Research, NOVA, located at Oslo Metropolitan University. State bureaucracies, e.g. ministries and directorates, municipalities etc. can ask for investigations and overviews. NOVA has an annual income for running the Youth Data through the Norwegian Directorate of Health of 3,3 mill. NOK (2018). The Youth Data registry has become a leading force in opinions, policies, polities and resource allocations for youth at municipal and state levels for several intended purposes. Based upon NOVA reports, media comments and interviews this article reflects upon some theoretical and methodological approaches to this unique epidemiological tool concerning youth, health and welfare. Questions arise such as: Is epidemiology a taken for granted neutral and objective kind of knowledge? Should there be ethical concerns for youth and their researchers as creators of knowledge, theory and policy - other than the normal ethical rules of scientific conduct?
\end{abstract}

This is an open access article distributed under the Creative Commons Attribution Licence, which permits unrestricted use, distribution, and reproduction in any medium, provided the original work is properly cited.

\section{INTRODUCTION}

"Tallenes tale er ikke alt - the voice of the numbers does not say everything" (Director of health Torbjørn Mork 1990:4) (my translation)

In this article I consider epidemiology as a science and epidemiologists and statisticians as administrators and developers of epidemiological scientific data, facts and perceived truths. I see the administrators as members of a social organization that manages not only knowledge about a specific measured phenomenon, but also as managers of a specific ideology of knowledge. Knowledge in this instance means knowledge in terms of e.g. perceived truths about youth. In going beyond "the mere facts" about youth groups, we may discern or discover why the epidemiology of perceived truth about youth contains several levels of truth as well as knowledge. The Youth Data Registry at NOVA (OsloMet) (see http://www.hioa.no/eng/AboutHiOA/Centre-for-Welfare-and-Labour-

Research/NOVA/Youth, downloaded Nov. 2018) will serve as a case for investigation.

Key terms for epidemiology as it originated during the $19^{\text {th }}$ century were the science of the incidence and prevalence of illnesses in a specific population or the distribution of illnesses within or between population groups or even the knowledge of the origins of illnesses in a specific population group.

Epidemiology takes its name from epidemics, e.g. infectious diseases. The interest, relevance and knowledge development dates at least back to Hippocrates. The recent two centuries saw that counting human, i.e. societal, phenomena, be that illnesses, or simply distribution of people and population groups into more and more refined knowledge, developed as governance tools for the growing state management of its population. Major areas of epidemiological studies include disease causation and surveillance, disease transmission and screening, disease outbreak investigations, forensic or occupational epidemiology, biomonitoring, comparisons of treatments and effects such as comparing clinical trials in double blind tests etc. Some of these methodological tools are widely known in the social sciences.

This global and totality scale of the development of the field has embraced new areas as a metaphor for other human situations and circumstances. From the $20^{\text {th }}$ century on epidemic, infection, contagion and danger or risk of contagion, infections or epidemics act as metaphors for other human phenomena than those that spread by virus or bacteria. Terms as social or mental contagion or epidemic are still used e.g. when describing suicide epidemics or intoxication (alcohol and drug) epidemics.

Questioning epidemiology as a tool for truth is a basic both ontological and epistemological question. In addition, the term «truth» calls for an ethical consideration of value, both of epidemiology as a particular field of knowledge and research as well as, and indirectly, of its users, the researchers. In addition, there are other epidemiological knowledge providers and disseminators, e.g. political actors and administrators, research institutes and policy makers.

Questions that I raise in this article concerns epidemiology as knowledge that is obvious and taken for granted, i.e. an essentializing ontology. Thus, when does a certain number symbolising or metaphorizing a particular feeling, point of view or previous experience become an unquestionable fact - and truth? What if a fact or a truth does not rest on a particular number - 
what are the consequences of the transformation from e.g. phenomena like feelings (or viewpoints or opinions) ... into countable oral or written experiences or expressions with feelings? (Snyder et al 1991). What if the epistemology of epidemiology became questioned as inappropriate for a whole range of research questions? Such questions necessarily lead to an overall conclusion: If epidemiology is regarded as a model for and of reality, how is reality fitted into epidemiology? There are numerous examples of this in our everyday life such as how income-based epidemiology is linking up to politics, e.g. the distribution of welfare goods in the population. Another example is the construction of tipping points such as self-enforcing creation of opinions, where simple truths push the complex ones aside, e.g. population polls on voting behaviour.

Epidemiology is a framework for the understanding and interpretation of numbers, dimensions and correlations. How does one explain or defend the transmission from such data to causations? How does one discern the entwining of contemporary science and research with politics, economy and technological innovation? Is the divide between the normative and the descriptive, possible? (Lie 2016).

Discussions among Norwegian medical professionals on the early 20th century's health education as part of state governed public health concern the fine line between improved living conditions - and control and manipulation (Hem, Nordhagen \& Børdahl 2018: 1638, see https://tidsskriftet.no/en/2018/10/medisinskhistorie/always-stay-cheerful-health-information1920s, downloaded Nov. 2018): "The line between social hygiene and general disciplining is blurred, for example the boundary between a healthy diet and bourgeois norms. The education of mothers and children also included a normative aspect that concerned good manners and control". The authors conclude with e.g. "Medical truths are claimed to have a constantly diminishing shelf life. Yesterday's recommendations are no longer valid today: 'Eat carrots while they are still healthy'. "Apart from the use of "truth" in epidemiology, the fine line between education and control in this example from public health education is of value for the further discussion in this article on epistemology of epidemiology. It also is an example of control and discipline history repeated, as I will come back to.

\section{Youth Data AS A CASE}

One of the reasons for my interpretation of Ungdata, Youth Data, as the most significant epidemiological tool for the perceived truth about contemporary Norwegian youth is to find in a significant amount of both scientific and more popular texts as well as the space given in different media:

"Ungdata is regarded as the most comprehensive source of information on adolescent health and well-being at the municipal and national levels. It is among other things used in municipal planning and developmental work related to public health and preventive measures aimed at young people.

Ungdata cover various aspects of young people's lives, e.g. relationships with parents and friends, leisure activities, health issues, local environment, well-being, and school issues. The surveys also include questions about tobacco and drug use, and participation in various forms of antisocial behavior such as violence and bullying.

NOVA is responsible for the national coordination of the project, while the regional Drug and Alcohol Competence Centers are responsible for conducting the municipal surveys. Norwegian Directorate of Health, Ministry of Children, Equality and Social Inclusion, Ministry of Justice and Public Security and Ministry of Education and Research have supported the development of Ungdata financially. From 2015, Ungdata is financed through the national budget.

The Ungdata material is collected online during school hours. The questionnaire has a fixed part, which is similar in all surveys. In addition, the form contains a number of elective questions that municipalities can choose based on interest and need. NOVA administers a national database, which contains all conducted surveys" (see http://www.ungdata.no/English, downloaded Nov. 2018).

Based upon NOVA reports, media comments and interviews, one may ask if there are some unintended consequences of this unique epidemiological tool concerning youth, health and welfare. Questions arise such as: Is epidemiology a taken for granted neutral and objective kind of knowledge? Should there be ethical concerns for youth and their researchers as creators of knowledge, theory and policy?

Interestingly enough, even in this particular special number of Norsk Epidemiologi on Youth, health and welfare, almost all of the ten invited articles have references to one or more publications from Youth Data.

My professional interest for the questions started decades ago. As both a physician and a social anthropologist I defended my dr. thesis in medicine with e.g. a trial lecture on "Strengths and weaknesses in the epidemiological approach to the study of social medical conditions" (Hydle 1991). I described how the managers of epidemiological investigations communicated by help of numbers and interpretation of numbers. The numbers act as tools for finding a sense with the problem under scrutiny and the results of a numerical investigation of the problem. Thus, one may see numbers as a classification that orders the chaotic, messy and complex into the lucid, understandable and thereby controllable. In general, chaos is linked to danger, threat and meaninglessness. Seen from an anthropological viewpoint, the epidemiologists order their world with the help of numbers and thereby grasping the control of reality. The numbers do not only 
become mere symbols of similarities and differences between population groups, based upon questionnaires, observations, tests etc., but also symbols of the control over human abilities, attributes, characteristics or qualities. In this way, epidemiologists may communicate with others through numbers and the language that escort the numbers. In short, a social construction that orders experience, as the sociologist Berger expresses about the socially constituted world that above all is that one orders, i.e. tidies up or clean, human experience (Berger \& Luckmann 1966:19).

\section{THEORETICAL REFLECTIONS}

Berger and also Luckmann with their Social construction of reality were to some extent forerunners at their time (1960s) for a growing interest in how social reality becomes constructed in scientific practices, together with e.g. Thomas Kuhn and his The structure of scientific revolutions, 1962 and Michel Foucault with his The Order of Things: An Archaeology of the Human Sciences (Les mots et les choses: Une archéologie des sciences humaines). Foucault was utterly clear and distinct in the emphasis on the role of power in scientific enterprises. Numerous theorists have followed along the clear tendency and development in human, social and natural sciences after the publications of these internationally renowned scholars. The increasing objectivation, measurement and standardisation constitute a cultural logic that forms four main dimensions in social life: meaning, representation, morality, and person - and thing-understanding (Larsen \& Røyrvik 2018: 7): Objectivation deals with the different ways "things" and thing-like entities such as classes and categories are produced as part of the cultural infrastructure in all societies.

New principles for such categorisations may be 'commodification', 'reification', 'fetishization', actornetwork theory etc. Larsen and Røyrvik refer to the $20^{\text {th }}$ and $21^{\text {st }}$ centuries as the centuries with a "quantification passion". In a Norwegian context the historian and legal theorist Slagstad investigated exactly this question in showing how the emergence of Norwegian welfare polity through these two centuries were closely knit with the emergence of epidemiology and statistics (Slagstad 1998).

We were a number of Norwegian scholars who developed the Foucauldian biopower- and knowledgeperspectives in the analyses of the governance or rather governmentality, the Foucauldian term, of various Norwegian public fields, such as the health field (Neuman \& Sending 2003). Government in this sense refers to a combination of governing and mentality, i.e. a conduct or an activity that is meant to create, shape, guide, or affect the conduct of people.

Thus quantification, measurements and standardisations, including the emergence of a culture of indicators, are social practices forming society and culture, according to the anthropologists Larsen and Røyrvik, also in referring to Merry (2011). In the aftermath of Foucault this is in most contemporary epistemological discussions clearly linked to power, be it social, cultural, or biological. In their anthology Larsen and Røyrvik look into such social practices as performative and generative technologies. Numbers are not only a form of representation along with narrativity or visualisation, but quantification, measurement and standardisation create new subjectivities and a spectre of normative guidance or provisions, i.e. new worldviews and conceptions. Historical investigations from 1800 on, e.g. of the emergence of the Norwegian health care system of today, show how not only the concept of society (Porter 1995), but also the concept of health and disease is a statistical construct (Hydle 1981, 2003). To answer the question of epidemiology as a neutral science, one first needs to examine how (statistical) facts are constructed, maintained and disseminated? With other words: How are new entities and categories extracted and presented as autonomous "things" in the world? (Latour, 2012). In my investigation into NOVA Youth Data, I will firstly present three examples from English summaries of NOVA Youth Data reports. In addition, I will look into the media coverage of the release of new NOVA Youth Data statistics.

\section{DATA EXAMPLES}

As an introduction there is no doubt that the last years NOVA Youth Data reports have underscored the problem of stress and mental problems among youth (Abebe et al., 2016).

1. "The Youth Data report on method "Ungdata junior 2017" summarizes "This report is an evaluation of "Ungdata junior 2017", a survey of the wellbeing of children aged $10-12$ years old $\left(5^{\text {th }}\right.$ to $7^{\text {th }}$ grade). The survey measures wellbeing by covering a wide range of aspects, such as friends, family, school, health, leisure activities, sleep, media use, and general wellbeing. In developing the survey, both the questionnaire and the method of data collection were thoroughly tested. We wanted an age appropriate questionnaire that grasped the salient aspects of children's lives relating to wellbeing. We also wanted a method of data collection that ensured informed and voluntary participation while at the same time being efficient and easy to participate in and organize for the respondents, schools and municipalities. Focus groups and a pilot study involving 200 children in the ages 10-12 years were therefore valuable tools in the development stages of the survey." (Løvgren \& Overå 2018, see http://www.hioa.no/Om-OsloMet/Senter-for-velferdsog-

arbeidslivsforskning/NOVA/Publikasjonar/Rapporter/ 2018/Ungdata-junior-2017.-Metoderapport)

(downloaded Nov. 2018).

2. "In recent decades, there has been an increase in self-reported internalizing mental health problems, 
such as depression and anxiety, among young people in many Western countries, including Norway. The aim of this study has been to increase knowledge about the prevalence and the reasons behind the increase in self-reported mental health problems among adolescents in Oslo, and how youths experience mental health problems. Analytically foregrounding gender, we have explored the relationship between mental health problems and pressure related to school, body image and social media use, and how demands in these different areas affect the lives of adolescent girls and boys. We have also studied how adolescents interpret questions about mental health problems asked in large surveys, and to what extent they experience that these questions address problematic issues for the youths who are affected." (Bakken 2016, see http://www.hioa.no/vitenogpraksis/Barn-ogunge/Psykiske-helseplager-fortsetter-aa-oeke-blantungdom) (downloaded Nov. 2018, my translation).

3. "One main finding is that Oslo is a good and safe place in which to grow up for most youth. The majority feels well in themselves, with their parents, at school and in their leisure time. At the same time there are development features of concern. In 2018 a considerably higher number of young people have used cannabis than in 2015, and there are more young people involve in problematic conduct. There is also an increase in the number of the youth that has been exposed to violence and bullying and also has different health problems. The changes happen on the whole across socio-economic borders and in all areas of the city". (see http://www.hioa.no/Om-OsloMet/Senterfor-velferds-og-

arbeidslivsforskning/NOVA/Publikasjonar/Rapporter/ 2018/Ung-i-Oslo-2018

(my translation)(downloaded Nov. 2018).

Media coverage of NOVA research results and publications is registered at NOVA, as part of an e.g. control and quality measurement of the research conducted. The media coverage from 2018 on Youth Data publications is as follows (up till 10. Oct. 2018, i.e. not yet for the whole year):

In total 1467 media references concerning Youth Data this year, up to 09.10 .2018 , were found. This comprises newspapers (texts or online), journals, municipal webs, TV and radio stations in all of the Norwegian 18 counties. 477 sources of reporting on the NOVA reports were found. There is reason to say that there is a widespread both national and local interest for the data and results produced by NOVA researchers.

One of many reports is from a nationally distributed weekly magazine sent to many Norwegian households across the country at the week-ends - "A-Magasinet" as a special weekly for the biggest newspaper Aftenposten. This report is presented both as the whole frontpage picture of a 10 years old girl that looks a bit disturbed and wondering at her school's timetable. The title underneath is:"Generasjon prestasjon junior". This title is a pun in Norwegian, 'prestasjon' means achievement or accomplishment - and the term has become popular among the general public. The magazine's editorial is called "Quality of life on the timetable" mainly concentrating on the new school year in the autumn and the psychological needs of young pupils in "life coping" and mental health, also as a new issue for education, both for teachers, educators and pupils. In the magazine 12 pages with pictures and interviews cover the title "Life coping shall into the school" with the subtitle: Is it possible to think of a better health? At Lysaker school (a school close to Oslo) class 3A has psychological first aid on their timetable". The article's main research basis is the NOVA national Youth Data investigation from 2017, in addition to the first junior Youth Data report on 10-12 years' old from two big municipalities close to Oslo - as a trial investigation. The journalist interviews and refers to several researchers, psychologists, the national school authorities and the Ministry of education in her report which tells us much about the impact and spreading of Youth Data in general. An 18 years old girl voices just a minute critique of the focus: "I hope that mental health does not become another thing that we young have to cope with" (my translation).

\section{YOUTH DATA AS PERCEIVED TRUTH ABOUT YOUTH?}

The public and partly private interests for the Youth Data are closely linked to the state and municipal governance of youth life, health and welfare. That the Youth Data also finds itself at the central government budget witnesses clearly about the need and interest of the research, the indicators, quantification and measurements of young lives in Norway. Thus there is a need to question these objectivizing technologies as cultural premises for our time, as I noted. They seem to come close to the representing of youths' lives, health and welfare. They also seem to enter into debates about leadership and governance, financial changes, identity politics and moral reorientation (Larsen \& Røyrvik 2018:13).

In following up on Larsen and Røyvik, the epistemology of epidemiology asks for the relationship between the measurer and the measured. In this case the measured are sitting in their classrooms at schools that are more and more governed by principles of subjectification, target-oriented management and socialization in the gaze of the market. They are also interviewed one by one or in focus groups. In addition, they may voluntarily meet the measurers in conversations about questions. It is important to know if questions and answers follow a specific logic in order to fit into the measurement instruments. Likewise we may need to question the transmission between the 10-12 years old and their becoming valuable tools for surveys.

Another set of reflections concern the status of the research institute NOVA as a political actor. Several 
Norwegian research institutes act as deliverers of facts and values for Norwegian governance of its population, finances, trade, environments etc. Most of these deliverables and the research groups or institutes are however in an open contest with others. NOVA's Youth Data, in contrast, seems to find itself in a kind of monopoly situation for the whole country, due to its wide distribution and dissemination. Not only do the data serve as governance tools for national and local political and administrative decisions, but also as ideas and thoughts, reflected in the media, on the e.g. health and wellbeing of youth. One question that may emerge is if this requires of NOVA an introspection into this particular position concerning politics, research policy and ethics.

A third set of reflections emerge from the interview with the young people, be they 10 or 18 old. They express in small letters or vaguely a concern that is the opposite to introvert, concerning their own mental health. They express concerns with the society of which they are members and its development. The same is referred to as a confirmation in other Youth Data publications. These kinds of societal concerns might be followed up in other surveys, interviews and focus groups with e.g. an aim of seeking advice by the youth population on future politics and governance of the state, Norway, not only of themselves, in introvert directed questions and answers. A significant number of pedagogues (Paolo Freire), philosophers (Frankfurt school, later Foucault, Agamben, Sen, Sommers, Nussbaum, Bauman, Deleuze...) have concentrated on exactly this problem of internalizing societal challenges, problems and dangers. Political challenges concerning whole population groups are turned into individual physical and mental health questions and problems, what is commonly called medicalization. There are extensive international financial, industrial and professional interests in medicalization because it causes e.g. new demands for psychologists, psychiatrists and psycho-pharmaceuticals. Larsen \& Røyrvik underscores the socialization in the gaze of the market, i.e. one of the "branches" of New Public Management.

A term that might serve as a helping hand is control, both as Foucault presented it (in e.g. 'Discipline and Punish' or in 'The Order of Things') as well as the Italian philosopher Giorgio Agamben who followed up on the Foucauldian terms biopower and governmentality. In a public lecture in Athens in 2014 he said (e.g. about European states): "The state in which we live now is no more a disciplinary state. Gilles Deleuze suggested to call it the État de contrôle, or control state, because what it wants is not to order and to impose discipline but rather to manage and to control. Deleuze's definition is correct, because management and control do not necessarily coincide with order and discipline. No one has told it so clearly as the Italian police officers, who, after the Genoa riots in July 2001 declared that the government did not want for the police to maintain order but for it to manage disorder" (Agamben 2014).

The most effective and elegant road for the state to manage societal disorder is to turn disorder into disturbances, unrest and mental problems, i.e. into a problem that has to be solved by each individual her- or himself - becoming their own "minister of health" or "minister of justice" ... and the earlier in life the more efficient.

\section{NOVA's YOUTH DATA AS GOVERNMENTALITY}

With the above approaches, I ask if it could be useful to look into how NOVA represents the state and how the state mirrors itself in NOVA research, its data and the handling of these data. Neumann asks for perspectives and approaches that visualise the state or bring the state to the foreground, not only as a system of bureaucracies, a structure of different state formations or a national power that brings about different, not always intended, effects in or for its population (2011, 2018). The state is recognised e.g. through the results of its actions. Not the least, indirect and subtle state formations may be discerned in state sponsored research institutes, such as NOVA. The actions, e.g. research methodologies as well as the publications, seminars and disseminations of the researchers as individuals or groups within special subfields of NOVA research issues may be analysed as representations of the state. The Foucauldian term governmentality is one of the three terms or tools that Foucault used to analyse state power, or rather the analysis of how and with what the state manages control through its inhabitants' own thoughts, ideas, knowledge and acts. Not only the actions of the researched and the researchers but also of the administrators of NOVA research might be analysed through the tool of governmentality. It might be of use as quality control of research, for conscientisation of epistemology.

The strategy memo from OsloMet 2018 says e.g. that the youth research is among the most visible at OsloMet, and the number of seminars, conferences, presentations and media coverages are very high. The Youth Data centre was awarded with the OsloMet's dissemination price for 2018. In addition, there is a considerable research dissemination through national and international journals, research reports, conference papers and policy briefs. During this period there is a goal-oriented work on a dissemination strategy considering several issues. The research section shall continue the work on a growing number of research articles and books. The Youth Data research has over time worked strategically in offering a masters curriculum through its Youth Data workshop. In 2017 a number of students were linked to the Youth Data workshop. It is a goal to broaden this lab offer with qualitative methods, too. Through the youth network at OsloMet there is a goal to offer at least one curriculum on the issue «youth». NOVA had in 2017, 17 different 
projects in the youth research field, with a contracted income of $15984000 \mathrm{NOK}$. The themes for the research embrace widely. NOVA will therefore currently assess the need for a certain increase in the number of youth researchers (see e.g. http://www.ungdata.no/English).

The question is if this also implies that NOVA becomes part of a governmentalising body in terms of furthering the particular kind of state-knowledge that is produced through the Youth Data bank and its publications. Youth Data researchers have contributed to a socio-demographic broadening of their data and publications of results. But, they add that they have not asked the youth themselves about this question (Stefansen \& Skevik 2006): (Vi har ikke data om hvordan ungene selv opplever den boligen de bor $i$; We do not have data on how the youngsters themselves experience their own dwelling, my translation). Several Youth Data publications refer to socio-economic variables, without the researchers' or the informants' opinions of why, e.g. why do youth and their parents drink more alcohol, why and how do socio-economic variables influence health and/or behaviour differently in particular and different parts of the population. This might lead to some particular cautions concerning data collection.

The social science scholar Karen Wells claims in her book "Childhood in a Global Perspective" (2009) that schools has an impact as moral technology. She refers to Foucault who developed this perspective of how governments govern through their institutions, schools, health care, social work, policing, law etc.. The institutions further the government's regulations of conduct of conduct, i.e. how people regulate themselves to get a the feeling of good conduct as in the heart of being a good person. All the institutions' ways of regulating peoples' conduct Foucault grouped together in the term technologies. The term also includes that both the institutions' professionals and their clients or patients may have entirely different intentions than those that emerge through these technologies. Foucault called them moral, because their aim is to change people's behaviour by their internalising what conduct create thoughts and feelings of being a moral person and doing good and right. Thus the fact of sampling data at e.g. schools, as a moral technological space for children, may create a particular response space both for researchers and informants.

Enforcing this perspective, we may refer to Wells in her study of a range of sub-disciplines (history, geography, sociology and anthropology) that constitute Childhood Studies. She shows how children's subject formation is not only pressed upon them from the outside. They also take it up themselves, shaped by their bodies and minds and through their cultural practices (Wells, 2018).

\section{CONCLUSION: UTOPIA, MYTHOLOGY OF TRUTHS AND YOUTH: POSSIBLE ALTERNATIVES?}

In an editorial in the prestigious journal Epidemiology, medical epidemiologist W. Douglas Thompson wrote: "If only we lived in an epidemiologist's utopia - a place where, for every disease we chose to study, we could identify all incidents arising over a specified period in a large and well-defined population and where, for each case, it would be possible to select at random one or more controls who are member of the population at risk and who are in the same stratum of that case. Alas, we do not live in such a place but must instead struggle along in a world of imperfect information and limited resources" (1990:262).

Mythology is the knowledge field of tales about human conditions, mostly social in their subject matter and concern origins or creations of some phenomena that may be natural, supernatural or sociocultural. Thus, Youth Data may be seen as a mythology of truths about youth. And the research work is no doubt and so far a secure source both of fame and income for NOVA. The continuing ensuring of spreading the knowledge is not only ensuring the knowledge of facts about youth, but also the knowledge of numbers as facts about youth. One of the best known epidemiologists of our time, Hans Rosling, called his latest book «Factfulness: - ten reasons we're wrong about the world - and why things are better than you think» (2018). Perhaps is one of the reasons why we are wrong about the world, that numbers only may reproduce facts about numbers, i.e. not about individual lives. Statistical facts do not have voices, as Mork claimed. Furthermore, the quality of voices, such as the harmony or disharmony of a choir, may not tell or explain the truth of the composition, nor of the composer. Perhaps it would be worthwhile to rethink the role of the composition and the composers of Youth Data as well?

The epidemiologists Jason Beckfield and Nancy Krieger have a new suggestion to this question in their article "Epi + demos + cracy: Linking Political Systems and Priorities to the Magnitude of Health Inequities Evidence, Gaps, and a Research Agenda" (2009). Their focus is on both social epidemiology and political sociology and investigations on how political systems and priorities shape health inequities. They referred to a systematic search of the ISI Web of Knowledge and PubMed databases and identified 45 studies, commencing in 1992, that explicitly and empirically tested, in relation to an a priori political hypothesis, for either 1) changes in the magnitude of health inequities or 2) significant cross-national differences in the magnitude of health inequities. $84 \%$ of the studies focused on the global North, and all clustered around four political factors: 1) the transition to a capitalist economy; 2) 
neoliberal restructuring; 3) welfare states; and 4) political incorporation of subordinated racial/ethnic, indigenous, and gender groups. In the critical summary of these studies' findings, they carefully attended to spatiotemporal scale, level, time frame e.g. life course, historical generation, choice of health outcomes, inclusion of polities, and specification of political mechanisms - to address the enormous gaps in knowledge that were identified.

This helps us perhaps to realise that epidemiology has its strengths, but also weaknesses and should be carefully applied as a research instrument for population studies. And, to follow up on the previous director of health, Torbjørn Mork: he added a significant caution to the use of epidemiological facts: "One thing is that the magical power of numbers has a tendency to reduce our ability to critical assessment of the quality and relevance of the basic data that enter into our statistics. Another and worse is that those sides of reality that are not so easy to quantify, get lost. We are seduced to think in average instead of in hospitalisation. The suffering and anxiety for the one who is awaiting a hospitalisation, is just the same whether the queue is long or short. The grief is just as deep and genuine for the parents who lose a child in the first week of life, even if the neonatal mortality is "only" 9 per 1000 living born. For the one who dies, is the bodily annihilation $100 \%$, even if the population mortality rate is low" (Mork 1990:4) (my translation).

Thus, a challenging epistemological option in the footsteps of Youth Data, would be to follow up on both Wells and Larsen and Røyrviks perspectives concerning new entities and categories of youth knowledge and how they are extracted and presented as autonomous "things" in the world. In addition to new insights into the epistemology of Youth Data, it might also lead to knowledge on state power and control.

\section{REFERENCES}

Abebe, D. S., Frøyland, L. R., Bakken, A., \& Von Soest, T. (2016). Municipal-level differences in depressive symptoms among adolescents in Norway: Results from the cross-national Ungdata study. Scandinavian Journal of Public Health 44 (1), 47-54.

Agamben, G. (2014). From the State of Control to a Praxis of Destituent Power, see https://roarmag.org/essays/agamben-destituent-power-democracy/ - downloaded Nov. 2018

Bakken, A. (2016). Ungdata 2016. Nasjonale resultater. NOVA Rapport 8, 16. http://www.hioa.no/vitenogpraksis/Barn-og-unge/Psykiske-helseplager-fortsetter-aa-oeke-blant-ungdom downloaded Nov. 2018.

Beckfield, J. \& Krieger, N. (2009). Epi + demos + cracy: Linking political systems and priorities to the magnitude of health inequities - evidence, gaps, and a research agenda. Epidemiologic Reviews 31, 152-77.

Berger, P. L. and Luckmann, T. (1966). The social construction of reality. New York: Penguin University Books.

Hem, E., Nordhagen, R. \& Børdahl, P.E. (2018). Vær alltid i godt humør - helseopplysning i 1920-årene. [Be always in a good mood - health education in the 1920s]. Tidsskrift for Den norske legeforening 138, 1638-44.

Hydle, I. (1981). Helsetjenesten i et internasjonalt perspektiv. In Sundby, P. ed. Sosial velferd og sosial omsorg. En innføring $i$ sosialmedisin [Social welfare and social care. An introduction to social medicine]. Oslo: Fabritius.

Hydle, I. (1991). Styrke og svakheter ved den epidemiologiske tilnorming til studiet av sosialmedisinske tilstander. Prøveforelesning for den medisinske doktorgrad. Oppgitt tema. [Strength and weaknesses with the epidemiological approach to social medical conditions. Trial lecture over a given subject to the medical $\mathrm{PhD}$ ]. Medical Faculty, University of Oslo.

Hydle, I. (2003). Regjering av helse [Government of health]. In Neuman, I. \& Sending, O.J. eds. Regjering $i$ Norge [Government in Norway]. Oslo: Pax.

Larsen, T. \& Røyrvik, E.A., eds. (2018). Trangen til å telle. Objektivering, måling og standardisering som samfunnspraksis. [The need to count. Objectivation, measurement and standardization as societal practice]. Oslo: Scandinavian Academic Press.

Latour, B. (2012). We have never been modern: Harvard University Press.

Lie, S.A.N. (2016). Philosophy of nature: rethinking naturalness. London: Routledge.

Løvgren, M. \& Overå, S. (2018). Evaluation of "Ungdata junior 2017, NOVA Report 3/18 (see http://www.hioa.no/eng/About-HiOA/Centre-for-Welfare-and-Labour-

Research/NOVA/Publikasjonar/Rapporter/2018/Evaluation-of-Ungdata-junior-2017, downloaded Nov. 2018).

Merry, S. E. (2011). Measuring the world: Indicators, human rights and global governance. Current Anthropology 52(3):83-95.

Mork, T. (1990). Tallenes tale sier ikke alt [The voice of the numbers does not say everything]. Intern info, Helsedirektoratet 14/90:4.

Neuman, I. B. \& Sending, O. J. eds. (2003). Regjering i Norge [Government in Norway]. Oslo: Pax. 
Neumann, I. B. (2011). Tilbake til Durkheim: Antropologien og Staten [Return to Durkheim: Anthropology and the State]. Oslo: Universitetsforlaget.

Neumann, I.B. (2018). Address to NOVA research seminar, Oct. 2018.

Porter, T. (1995). Trust in Numbers: The Pursuit of Objectivity in Science and Public Life. Princeton, N.J. Princeton University Press.

Rosling, H., Rosling, O., \& Rönnlund, A. R. (2018). Factfulness: Ten Reasons We're Wrong about the World and why Things are Better Than You Think. London: St Martin's Press.

Slagstad, R. (1998). De nasjonale strateger [The national strategists]. Oslo: Pax.

Snyder, C. R., Harris, C., Anderson, J. R., Holleran, S. A., Irving, L. M., Sigmon, S. T. \& Harney, P. (1991). The will and the ways: development and validation of an individual-differences measure of hope. Journal of Personality and Social Psychology 60(4): 570.

Stefansen, K. \& Skevik, A. (2006). Når fattige barn faller utenfor [When poor children are excluded] Klassekampen, Med andre ord-spalten. 25.04.2006.

Thompson, W. D. (1990). Non-random yet unbiased, Epidemiology 1(4):262-265.

Wells, K. (2009). Childhood in a Global Perspective. London: Polity.

Wells, K. (2018). Childhood studies: making young subjects. Cambridge: Polity Press. 